\title{
Clinical importance of the Mandalay Spitting Cobra (Naja mandalayensis) in Upper Myanmar - bites, envenoming and ophthalmia
}

Sai-Sein-Lin-Oo ${ }^{1}$, Myat-Thet-Nwe ${ }^{2}$, Khin-Maung-Gyi ${ }^{1}$, Than-Aye ${ }^{3}$, Mi-Mi-Khine ${ }^{3}$, Myat-Myat-Thein ${ }^{2}$, Myo-Thant ${ }^{2}$, Pyae-Phyo-Aung ${ }^{2}$, Oakkar-Kyaw-Khant ${ }^{2}$, AyeZarchi-San ${ }^{2}$, Du-Wun-Moe ${ }^{2}$, Htay-Aung ${ }^{4}$, Mark O'Shea ${ }^{5}$, Mohammad Afzal Mahmood $^{6}$, Chen Au Peh ${ }^{6,7}$, Julian White, ${ }^{6,8}$ and David A. Warrell ${ }^{9 *}$

${ }^{1}$ Department of Zoology, Kyaing Tong University, Keng Tung, Myanmar

${ }^{2}$ Myanmar Snakebite Project, Mandalay Office, Myanmar

${ }^{3}$ Department of Zoology, University of Medicine, Mandalay, Myanmar

${ }^{4}$ Kyaukse Hospital, Kyaukse, Myanmar (deceased)

${ }^{5}$ Faculty of Science \& Engineering, University of Wolverhampton, UK

${ }^{6}$ University of Adelaide, Adelaide, Australia

${ }^{7}$ Department of Renal Medicine, Royal Adelaide Hospital, Adelaide, Australia

${ }^{8}$ Department of Toxinology, Women's and Children's Hospital, Adelaide, Australia

${ }^{9}$ Nuffield Department of Clinical Medicine, University of Oxford, UK

*Corresponding author david.warrell@ndm.ox.ac.uk 


\begin{abstract}
Examination of 18 cobras brought to three hospitals in the Mandalay Region by patients bitten or spat at by them distinguished 3 monocled cobras (Naja kaouthia) and 15 Mandalay spitting cobras ( $N$. mandalayensis), based on their morphological characteristics. We confirm and extend the known distributions and habitats of both $N$. mandalayensis and N. kaouthia in Upper Myanmar. Clinical symptoms of local and systemic envenoming by $N$. mandalayensis are described for the first time. These included local swelling, blistering and necrosis and systemic neurotoxicity. More information is needed about the clinical phenotype and management of bites by $N$. mandalayensis, the commoner of the two cobras in Upper Myanmar. Since the current cobra antivenom manufactured in Myanmar has lower pre-clinical efficacy against $N$. mandalayensis than N. kaouthia, there is a need for more specific antivenom therapy.
\end{abstract}

Highlights:

- $\quad$ The Mandalay spitting cobra (Naja mandalayensis) is much more common that the monocle cobra (N. kaouthia) in Upper Myanmar

- Injuries caused by spitting of venom and bites were admitted to three hospitals in Mandalay Division

- The known distribution of both species of cobra is extended

- Naja mandalayensis envenoming causes neurotoxicity as well as local tissue damage 
- The only available cobra antivenom in Myanmar may not be adequate for treating envenoming by $N$. mandalayensis

Key words:

Naja mandalayensis, Naja kaouthia, spitting cobra, venom ophthalmia, neurotoxic envenoming, local necrosis, antivenom, Upper Myanmar 


\section{Introduction}

Snakebite is a serious medical problem in rural areas of Myanmar. In 2014, 15,080 snakebites and 305 snakebite deaths were recorded by the Myanmar Ministry of Health (Regional Office for South-East Asia, World Health Organization, 2016), but a recent community-based study has suggested a much higher figure of perhaps 2,000 deaths per year (Mahmood et al., 2018). In Myanmar, there are three families of medically important venomous snakes: Elapidae (kraits, cobras, king cobra, Asian coral snakes and sea-snakes), Viperidae (Fea's viper, Russell's viper and pit-vipers), and Natricidae (red-necked keel-back, Rhabdophis subminiatus helleri and possibly some of the other six Myanmar species in this genus, including those formerly assigned to Macropisthodon) (Leviton et al., 2008). Species that are likely to cause snakebite envenoming include Bungarus magnimaculatus, B. wanghaotingi, Naja kaouthia, $N$. mandalayenis, Daboia siamensis, Trimeresurus (Trimeresurus) albolabris, T. (T.) erythrurus, and T. (T.) purpureomaculatus. Of these, Eastern Russell's vipers (D. siamensis) are by far the most important, causing more than $50 \%$ of medically significant snakebite cases and fatalities. In 2016, 16,767 snakebite cases were reported in Myanmar, with 2,566 cases in the Mandalay Region alone (Ministry of Health and Sports, Health Statistics Data, 2016).

Cobras are among the most familiar venomous snakes in Myanmar and are responsible for a considerable number of severe snakebite envenomings. They are distributed throughout the country, although records are so far lacking for the East (Shan, Kayah and Kayin states) and South-East (Mon State and Tanintharyi Division) (Leviton et al., 2008). 
It was long thought that Myanmar harboured only one species of cobra, N. kaouthia, easily recognisable by the single eye pattern on the back of its hood. However, back in 1900, Captain MD Goring Jones of the $2^{\text {nd }}$ Durham Light Infantry, wrote to the Journal of the Bombay Natural History Society describing the plight of a colleague who attacked a snake seen near his quarters. "The snake made a dart at him but fortunately missed its aim. Some of the poison or saliva was ejected into (his) eye, causing instant and great pain, and the eyelids and parts round swelled up quickly to the size of a large hen's egg. The snake was killed and found to be a small black cobra about 3 feet 4 inches in length. (The victim) went to hospital and after a painful night recovered his eyesight" (Goring Jones; 1900). This was the first clue that there might be spitting cobras in Upper Myanmar. These suspicions were supported by experience of keepers at Mandalay and Yangon zoos who were spat at by cobras (Dr U Tun-Pe, personal communication) and by the discovery of 6 specimens in the Stockholm Museum "with highly modified spitting fangs from Rangoon or Mandalay" which, on the basis of multivariate analysis of a range of morphological characters, "were not clearly assignable to any of the nine species (of Asian Naja) currently recognized" (Wüster and Thorpe, 1992). These authors predicted that "a species of cobra with spitting fangs occurs sympatrically with N. kaouthia in parts of Burma”. In India, some populations of $N$. kaouthia are capable of spitting their venom. In 2010, one of us (JW) observed this behavior in an adult $N$. kaouthia, captured near Kolkata in West Bengal (NEW Fig. 1). Vishal Santra, who had rescued the snake, had seen spitting by others of this species on multiple occasions (Santra and Wüster, 2017). However, spiting by this species has never been reported in Myanmar.

Eventually, Slowinski and Wüster described the Mandalay spitting cobra ( $N$. mandalayensis) as a new species from central Myanmar, based on morphological and molecular analyses (Slowinski and Wüster, 2000). It is apparently restricted to the central arid regions of Myanmar, thriving around villages and in agricultural land (Leviton et al. 2008). The present study aims to investigate and compare the morphometric characters of N. kaouthia and N. mandalayenis in the Mandalay Region, including an examination of their sympatry, and to describe, for the first time, clinical features of envenoming by the latter species. 


\section{Methods}

Snakes brought in by patients who had been bitten or spat at were collected from December 2016 to October 2018 at three hospitals (Mandalay General (MGH), Kyaukse District and Madaya Township Hospitals) in Mandalay Division, Myanmar as part of the Myanmar Snakebite Project (White et al; 2019a,b). The body cavities of all specimens were incised along the ventral surface and the snakes preserved in $70 \%$ ethanol for further studies and deposited at the Department of Zoology, Institute of Medicine, Mandalay. A number of morphological characters, lepidosis, colour pattern and body proportions were recorded (Table 1). The number of ventral scales from the head to vent was counted according to Dowling (1951). Thorpe (1975) pointed out that using ventral scales and subcaudal scales as units to define the position of morphological features was unsatisfactory because the numbers of scales varied between specimens. To correct for this variation, percent ventral scale $(\% \mathrm{VS})$ position was used to indicate the position at which dorsal rows of scales were counted (Slowinski and Wüster, 2000).

Clinical data were recorded manually on proformas by medical officers employed by the Australian Department of Foreign Affairs and Trade (DFAT)-funded Myanmar Snakebite Project (MSP), then entered into a tailor-made FileMakerPro database (White et al, 2019b). We also reviewed the original hospital case records to confirm the data and collect additional information. Dead snakes brought by patients were collected, identified, measured and labelled with individual tags bearing an ID number that was linked with the patient's own ID. 


\section{Results}

Snakes: eighteen out of a total of 212 dead snakes collected were cobras (Table 1). Thirteen patients proved to have been bitten by N. mandalayensis and 3 by N. kaouthia. Two patients were spat at by N. mandalayensis. All 15 specimens of N. mandalayensis had been encountered in Myanmar's central dry region - in Shwebo Township (1),

Sagaing Region; Kume (1), Kyaukse (4), Myitthar (2), Natogyi (2) Sintgaing (1), Thabeikgyin (1), Wun Dwin (1), and Pyin Oo Lwin (Shan Highland) (1) townships, Mandalay Region; and Salin Township (1) in Magway Region (Fig. 2). The three specimens of N. kaouthia had been killed, one each in Kyaukse (1) and Sintgaing (1), Mandalay Region and Kaw Lin (1), Sagaing Region. The two species were evidently sympatric in Kyaukse and Sintgaing.

The following morphological differences were used to distinguish the two cobra species:

(1) Fangs: all the fangs of $N$. mandalayensis were examined but some were broken. Wherever possible, we examined and measured the position and size of fang orifices, an important adaptation for spitting. The length of fangs was measured as the straightline distance between the distal end of the basal orifice and the tip of the fang according to Wüster and Thorpe (1992). These measurements were taken by digital caliper with an accuracy of $0.01 \mathrm{~mm}$. The fang length of $N$. mandalayensis was $5.3 \mathrm{~mm}$ (SD 0.29, $\mathrm{n}=4$ ) and the discharge orifice was $0.26 \mathrm{~mm}$ (SD 0.02, n=3) in length (Fig. 3 A-C). The fang has no groove and its discharge orifice is located away from the tip of the fang whereas in N. kaouthia and N. naja the orifice is longer, in a groove, and closer to the tip (Fig. 3 D-E). 
(2) Hood markings: none of the 15 specimens of $N$. mandalayensis showed any clear dorsal hood marking, although a faint suggestion of a spectacle marking was discernible in a few. All specimens of N. kaouthia had a monocle marking (Fig. 4A and B).

(3) Throat pattern: all specimens of $N$. mandalayensis showed dark mottling under the throat from the first ventral scale to the first throat band (between ventral scales 113), while all N. kaouthia had a pale, creamy-coloured throat with two distinctive lateral black spots ("false eyes") within a circular pale area. N. mandalayensis usually has pale-coloured ventrals/subcaudals distal to the throat area, whereas in N. kaouthia these are usually dark grey. Ventral and dorsal scale counts overlapped between the two species, but their dorsal hood markings and ventral throat markings were quite different (Fig. 4 A and B, Fig. 5).

A living specimen of $N$. mandalayensis from Taungdwingyi was photographed and is included to show some of the distinguishing features of this species (Figs. 6 A and B).

Patients: the total number of cobra bite and spit victims recorded was 18 (15 males and 3 females). Some victims were farmers, bitten while working (44\%). One victim was bitten (5\%) when he stepped on the snake accidently while riding a motorbike, four were bitten in their homes $(22 \%)$, while the remainder were bitten under unknown circumstances $(29 \%)$.

\section{Clinical features (Table 2)}

Symptoms and signs: most patients were bitten on their feet. Eight of the $N$. mandalayensis victims developed local swelling, with local bleeding from the bite wounds in 2, blistering in 2, local lymphadenopathy in 2 , and local necrosis in 4 . Local infection was suspected in 3. All 3 N. kaouthia victims developed local swelling, with local bleeding or local lymphadenopathy in 2 of them. One or more of the following 
systemic neurotoxic symptoms/signs were recorded in 5 of the 15 patients bitten by $N$. mandalayensis (33\%): bilateral ptosis, blurred vision (a subjective symptom possibly attributable to paralysis of visual accommodation or external ophthalmoplegia), slurred speech, inability fully to open the mouth, difficulty in swallowing, respiratory distress, and drowsiness. Two of the 3 patients bitten by $N$. kaouthia (67\%) had either blurred vision or sleepiness.

Two patients had venom spat into their eyes by $N$. mandalayensis, but they were not bitten. There was redness, lacrimation, periocular swelling and a burning sensation in the affected eyes (Table 2).

Laboratory tests: results were available in 7 N. mandalayensis and 1 of the N. kaouthia cases. They were normal apart from raised white blood cell counts in 2 of the $N$. mandalayensis cases and a mildly raised serum creatinine in one N. kaouthia case. There was no suggestion of coagulopathy in any of these cobra-bite cases: the 20 minute whole blood clotting test (20WBCT) was negative (clotting) in the 13 cases where a result was recorded; no patient had clinical evidence of systemic bleeding.

Treatment: no patient required intubation or assisted ventilation. Antivenom was administrated to $60 \%$ (9 out of 15 ) of victims of $N$. mandalayensis and in two out of three bitten by N. kaouthia. Most received Burma Pharmaceutical Industry (BPI) cobra antivenom; only 2 patients received Indian polyvalent antivenom (producer unknown). The dose was four to fifteen vials $(40-150 \mathrm{~mL})$. Only one (acute, pyrogenic) antivenom reaction was recorded. The patients who received antivenom were discharged after periods of observation ranging from 2 to 7 days.

Illustrative case report (Table 2, Case 10)

A 40 year old farmer was bitten on his right foot by a cobra at 1900h in October 2018 in Yin Ma Village, Salin, Minbu District, Magway Division. The snake was killed and 
brought in by the patient and was later identified as a Naja mandalayensis $116 \mathrm{~cm}$ in total length. By 2200h, he had developed slurred speech and difficulty swallowing, prompting his travelling $50 \mathrm{~km}$ over night to Seikphyu Township Hospital, arriving the following morning at 0600h. There, he received 4 vials of BPI (Burma Pharmaceutical Industry) Naja kaouthia antivenom after which his symptoms were said to have improved. However, because of his need for intensive care, he then transferred across the Ayeyarwady River, $270 \mathrm{~km}$ to Mandalay General Hospital, arriving at $1300 \mathrm{~h}, 18$ hours post-bite. On admission, he appeared drowsy (probably due to bilateral ptosis - see below) and complained of blurred vision, had difficulty swallowing and could not open his mouth. One-and-a-half hours later he was fully rousable (GCS 15/15) and febrile. His breathing was shallow, rate 20/min, but oxygen saturation was $98 \%$ while breathing $2 \mathrm{~L} / \mathrm{min}$ of oxygen via nasal catheters. His cough was ineffective. He had mild ptosis, limited mouth opening (maximum inter-dental distance $2 \mathrm{~cm}$ ), mild dysarthria and dysphagia. Power in all four limbs was normal $(5 / 5)$. He could raise his head normally and sit up unassisted. Examination of the bite site showed local swelling $(2+)$ with skin necrosis $(1+)$. The right inguinal lymph nodes were enlarged and tender $(1+)$. Laboratory investigations were normal (blood urea of $7.8 \mathrm{mmol} / \mathrm{L}$, serum creatinine $86 \mu \mathrm{mol} / \mathrm{L}$, plasma sodium $140 \mathrm{mmol} / \mathrm{L}$, potassium $3.9 \mathrm{mmol} / \mathrm{L}$, chloride $102 \mathrm{mmol} / \mathrm{L}$, bicarbonate $25 \mathrm{mmol} / \mathrm{L}$, haemoglobin $13.4 \mathrm{gm} / \mathrm{L}$ ) apart from a raised white blood cell count of $15,150 / \mathrm{ml}$ consistent with the inflammatory response to systemic envenoming. Because of persistent neurotoxic symptoms, he was given a further 4 vials of BPI Naja kaouthia antivenom, in the emergency department, 20 hours post-bite. Fourteen hours later, he was said to be stable. Subsequently, his symptoms improved and he was moved out of ICU to a general medical ward. Three days post-bite, the right leg remained swollen. The bite site felt warm, had developed blistering, and was diffusely tender. A course of intravenous levofloxacin and metronidazole was started and tetanus toxoid was administered. He made a full recovery and was discharged home after a 10 day admission.

\section{Discussion}


The venom apparatus and fangs of the Mandalay spitting cobra (N. mandalayensis) are adapted for spitting its venom defensively towards the eyes of perceived enemies. Compared to non-spitting cobras, the orifice of the venom duct in spitting species is smaller and situated further from the tip of the fang (Wüster et al., 1992; Slowinski and Wüster, 2000; Chu et al., 2010). Like Goring Jones (1900) more than a century earlier, Tun-Pe et al., (2002) reported ophthalmia caused by spitting of venom. Two villagers in the Mandalay Region and 6 snake keepers in the Mandalay Zoo (the Yadanabon Zoological Gardens) and Burma Pharmaceutical Industry's snake farm were spat at. Symptoms included pain and redness of the eyes, swelling and itching that usually resolved overnight. However, one 17-year-old girl suffered impairment of vision and unreactive pupils that resolved completely only after 3 days.

The medical importance and clinical features of $N$. mandalayensis envenoming in Myanmar, relative to those of the monocled cobra $N$. kaouthia were largely unknown. White et al., (2019a) assumed that the clinical effects of envenoming by $N$. mandalayensis involved local tissue injury with little or no neurotoxicity. However, we describe here, for the first time, clinical features of proven $N$. mandalayensis envenoming: local pain, swelling, numbness, lymphadenopathy, blistering and necrosis and systemic neurotoxic symptoms/signs including ptosis, blurred vision, slurred speech, inability to open the mouth, difficulty in swallowing and respiratory distress. This objective evidence of systemic neurotoxic envenoming in 4 cases, in addition to severe local envenoming in 6 of the 15 cases, is consistent with anecdotal accounts from physicians working in Mandalay, Sagaing and Magway Regions, and with reports of envenoming by two other SE Asian species of spitting cobra, $N$. siamensis (Wüster et al., 1997) and N. sumatrana (Reid, 1964). The clinical phenotype needs to be confirmed 
by larger prospective studies in which there is rigorous clinical documentation of neurological signs and identification of the biting snake.

Unfortunately, clinical signs do not differentiate between $N$. mandalayensis and $N$. kaouthia envenoming, making it impossible to make a species diagnosis unless the dead snake is brought or photographed. Even if this evidence were available, medical staff in Myanmar are insufficiently aware of the two species of cobras to be able to identify them reliably. We recommend that the curriculum for training medical staff and national treatment guidelines should illustrate the distinctive morphological features (dorsal hood and ventral throat markings) that differentiate Myanmar's two species of cobra. This may be clinically important because of what is known about the potency and neutralization of $N$. mandalayensis venom by the only cobra antivenom available in Myanmar, BPI (formerly MPF) cobra antivenom which is raised against N. kaouthia venom. Antivenom raised against the venom of one species of cobra may be ineffective in neutralizing the venom of other species because Asiatic Naja vary considerably in their venom composition (Wüster, 1996, Wüster and Thorpe, 1991). There is also variation in venom composition within a single species (Shashidharamurthy and Kemparaju, 2007). However, Aye-Aye-Myint et al., (2004) found that BPI cobra antivenom, neutralized the lethal effect of $N$. mandalayensis venom in mice, although this required a 10 times higher dose than was needed for $N$. kaouthia venom, despite the fact that the potency of $N$. mandalayensis venom, measured as the intravenous median lethal dose ( $\left.\mathrm{LD}_{50 \mathrm{iv}}\right)$, was $56.1 \mu \mathrm{g} /$ mouse, 10 times less potent than $N$. kaouthia venom ( $\mathrm{LD}_{50 \mathrm{iv}} 4.95 \mu \mathrm{g} / \mathrm{mouse}$ ). Similarly, in Thailand, the $\mathrm{LD}_{50 \mathrm{iv}}$ of Indo-Chinese spitting cobra venom ( $N$. siamensis) $(21.4 \mu \mathrm{g} /$ mouse $)$ was also less potent than $N$. kaouthia venom (LD50iv $6.61 \mu \mathrm{g} /$ mouse) (Khow et al., 1997). These results in mice suggest that patients with systemic envenoming by $N$. mandalayensis may require 
substantially larger doses of BPI cobra antivenom than the minimum initial dose of 4 vials $(40 \mathrm{~mL})$ currently recommended for $N$. kaouthia envenoming in Myanmar. Therefore, higher doses of BPI cobra antivenom may be appropriate for victims of identified $N$. mandalayensis envenoming. Pre-clinical testing against $N$. mandalayensis venom of other regional Naja antivenoms, such as Thai Red Cross Society N. kaouthia and neuro-polyvalent, and Taiwan $N$. atra antivenoms, might prove informative. In future, BPI should be encouraged to investigate the relative effectiveness of their cobra antivenom to determine if $N$. mandalayensis and $N$. kaouthia venoms should be combined in production of a bivalent cobra antivenom.

Prior to this study, Naja mandalayensis was known from only 20 specimens, some of them obtained from commercial snake collectors (Slowinski and Wüster, 2000). The activities of (now illegal) snake smugglers who trade cobras and Russell's vipers for medicinal use in China may have led to a decline in their numbers in recent years. By dint of its restricted range and commercial exploitation, the IUCN Red List of Threatened Species (http://dx.doi.org/10.2305/IUCN.UK.20121.RLTS.T192227A2058297.en) classifies it as "Vulnerable B1ab (iii,v) ver 3.1" (Wogan and Stuart, 2012). However, it is well known for its spitting habit among villagers in the central dry zone, and, in the early 2000s, within the space of one year, 700 spitting cobras, ostensibly caught around Thazi in Mandalay Division, were brought by commercial snake catchers to the national antivenom producer, MPF (BPI). We can now confirm that, within the catchment areas of Mandalay, Kyaukse and Madaya hospitals, N. mandalayensis is the commoner species of cobra.

Slowinski and Wüster (2000) believed its distribution to be restricted to the central dry zone of Myanmar - Mandalay, Magway and Sagaing Regions in dry forests and dry 
acacia habitat where the precipitation is less than $1,000 \mathrm{~mm}$ of annual rainfall. We have confirmed this, with the 15 specimens brought to our three study sites, and 3 additional records from Kyaukse and Myingyan in Mandalay Region and Thaungdwingyi in Magway Region (Fig. 5). However, one of our specimens was collected from Zee Pin Gyi Village, Pyin Oo Lwin Township, which is located in the Shan Highlands at an elevation of approximately $700 \mathrm{~m}$ above sea level and has an annual rainfall exceeding $1000 \mathrm{~mm}$. However, snakes confiscated from illegal traders heading for the border are sometimes released into the wild, artificially introducing them into new environments.

The distribution of $N$. kaouthia has been reported to exclude Mandalay Region. According to Leviton et al., 2008, "in the drier central region, spanning Mandalay, Magway [part], and Sagaing [part] Divisions, it (N. kaouthia) is replaced by Naja mandalayensis" (Leviton et al., 2008). However, our two specimens of N. kaouthia from Kyaukse and Sintgaing, Mandalay Region, together with a specimen collected in 1913 in Pyawbwe, Mandalay Region (Museum of Bombay Natural History Society \# BNHS 2263) establish its existence there, where it is sympatric with $N$. mandalayensis as in parts of Magway and Sagaing Regions.

\section{Conclusions}

Pending further studies, we conclude that, in the central dry zones of Mandalay, Sagaing and Magway Regions, the Mandalay spitting cobra is a species of medical importance, due both to its bites and defensive spitting behavior. Provisional evidence of cross-neutralising activity of BPI cobra antivenom raised against the venom of the more widespread monocled cobra is not entirely reassuring. Disparities between the lethal potency of the two cobra venoms and the median effective doses of antivenom suggest that the existing antivenom is unlikely to be effective against Mandalay spitting 
cobra venom, unless given in higher doses. Precise identification of the cobra species involved in envenoming patients is required to provide more substantial clinical data, while further research on the effectiveness of existing BPI cobra antivenom in neutralizing spitting cobra venom will determine if a case for producing a bivalent BPI cobra antivenom can be justified.

\section{REFERENCES}

Aye-Aye-Myint., Pe, T. and Maw, T.Z. (2004) Cross neutralization of cobra, Naja kaouthia antivenom manufactured by Myanmar Pharmaceutical factory with spitting cobra, N. mandalayensis venom. The Myanmar Health Sciences Research Journal, 16:11-13

Chu, E.R, Weinstein, S.A, White, J., and Warrell, D.A., 2010. Venom ophthalmia caused by venoms of spitting elapid and other snakes: Report of ten cases with review of epidemiology, clinical features, pathophysiology and management. Toxicon. 1:56(3):259-72.

Dowling, H.G. (1951). A proposed standard system of counting ventrals in snakes. Brit. J. Herp. 1(5): 97-99.

Goring Jones, M.D. (1900). Can a cobra eject its venom? J. Bombay Nat. Hist. Soc. 13: 376

Khow, O., Pakmanee, N., Chanhome, L., Sriprapat, S., Omori-Satoh, T., and Sitprija, V. (1997). Cross-neutralisation of Thai cobra, Naja kaouthia and spitting cobra, Naja siamensis by Thai cobra antivenoms. Toxicon, 11:1649-1651 
Leviton, A.E., Zug, G.R., Vindum, J.V. and Wogan, G.O.U. (2008) Dangerously venomous snakes of Myanmar. California Academy of Sciences. San Francisco, California, USA.

Mahmood, M.A., Halliday, .D, Cumming, R., Khin-Thida Thwin, Mya Myint Zu Kyaw, White, J., Alfred, S., Warrell, D., Bacon, D., Win Naing, Myat Myat Thein, Nyein Nyein Chit, Serhal, S., Peh, C.A. (2018) Snakebite incidence in two townships in Mandalay Division, Myanmar. PLOS Neglected Tropical Diseases, 1-12

Ministry of Health and Sports, Health Statistics Data 2016. MOHS, Nay Pyi Taw, Myanmar

Regional Office for South-East Asia, World Health Organization. (2016). Guidelines for the management of snakebites, 2nd ed. WHO Regional Office for SouthEast Asia. https://apps.who.int/iris/handle/10665/249547

Reid, H.A. (1964) Cobra bites. Brit Med J 2:540-545.

Santra V., Wüster W. Naja kaouthia (Monocled Cobra) (2017). Behaviour/ spitting. Herpetol. Rev. 48(2):455-456.

Shashidharamurthy, R. and Kemparaju, K. (2007) Region-specific neutralization of Indian cobra (Naja naja) venom by polyclonal antibody raised against the eastern regional venom: A comparative study of the venoms from three different geographical distributions. Int Immunopharmacol, 7 (1): 61-9.

Slowinski, J.B. and Wüster, W. (2000) A new cobra (Elapidae: Naja) from Myanmar (Burma). Herpetologica, 56(2): 257-270 
Thorpe, R.S. (1975) Quantitative handling of characters useful in snake systematics with particular reference to intraspecific variation in the Ringed Snake Natrix natrix (L.) Biol. J. Linn. Soc., 7: 27-43

Tun-Pe., Htut, T., Myint, A.A. and Yun, M.T. (2002) Venom ophthalmia following spitting of venom into the eyes by spitting cobra (Naja mandalyensis) in Myanmar. The Myanmar Health Sciences Research Journal, 14:42-44

White, J., Alfred, S., Bates, D., Mahmood, M.A., Warrell, D., Cumming, R., Thwin, K.T., Thein, M.M., Thant, M., Naung, Z.M., Naing, Y.H., San, S.S.S., Nwe, M.T. and Peh, C.A. (2019a). Twelve month prospective study of snakebite in a major teaching hospital in Mandalay, Myanmar; Myanmar Snakebite Project (MSP). Toxicon $X 1,1-6$

White, J., Alfred, S., Mahmood, A., Warrell, D.A., Cumming, R., Bates, D., Khin Thida Thwin, Aung Zaw, Moody, J., Eagles, D., Ragas, K., Dunstan, N., Peh, C.A. (2019b). An approach to managing a neglected, neglected tropical disease; the Myanmar snakebite project. Toxicon XXX. Toxicon (in press).

Wogan, G. and Stuart, B. (2012) Naja mandalayensis. The IUCN Red List of Threatened Species 2012: e.T192227A2058297.

Wüster, W. (1996). Taxonomic changes and toxicology: systematic revisions of the Asiatic cobra, Naja naja species complex. Toxicon, 34 (4): 399-406

Wüster, W. and Thorpe, R.S. (1991). Asiatic cobras: Systematics and snakebite. Experientia 47, 205-209

Wüster, W. and Thorpe, R.S. (1992). Dentitional phenomena in cobras revisited: spitting and fang structure in the Asiatic species of Naja (Serpentes: Elapidae). Experientia 48, 424-434 
Wüster, W., Otsuka, S. Malhotra, A. and Thorpe, R. (1992) Population systematic of Russell's viper: a multivariate study. Biological Journal of the Linnean Society, 47: $97-113$

Wüster, W., Warrell, D.A., Cox, M. J., Jintakune, P., Nabhitabhata, J. J. (1997). Redescription of Naja siamensis (Serpentes: Elapidae), a widely overlooked spitting cobra from S.E. Asia: geographic variation, medical importance and designation of a neotype Zool., Lond. 243, 771-788. 
Table 1. Relative parametric and meristic data recorded on Naja kaouthia and $N$. mandalayensis from the dry zone of Myanmar.

\begin{tabular}{ccc}
\hline & N. kaouthia $(\mathrm{n}=3)$ & N. mandalayensis $(\mathrm{n}=15)$ \\
\hline Ventral scales & $180-181$ & $175-188$ \\
Subcaudal scales & $54-57$ & $52-60$ \\
Dorsal row at $10^{\text {th }}$ ventral & $25-26$ & $19-23$ \\
Dorsal rows at midbody & $19-21$ & $14-18$ \\
Dorsal rows at $80 \%$ VS & $15-16$ & none \\
length & & $6-8$ \\
Dorsal hood marking & monocle & \\
Number of ventrals in & $53-92 \mathrm{~cm}$ & \\
first (anterior) dark throat & & \\
band & & \\
\hline
\end{tabular}

Table 2 (see new version attached) 
Table 2. Signs and symptoms of envenoming by two species of cobra in 18 patients

\begin{tabular}{|c|c|c|c|c|c|c|c|c|}
\hline $\begin{array}{l}\text { Patient } \\
\text { No. }\end{array}$ & $\begin{array}{l}\text { Age \& } \\
\text { Gender }\end{array}$ & Species & $\begin{array}{c}\text { Total } \\
\text { length } \\
\text { of snake }\end{array}$ & $\begin{array}{c}\text { Site of } \\
\text { bite/spit }\end{array}$ & $\begin{array}{l}\text { Local symptoms/signs } \\
\text { at the bite site }\end{array}$ & $\begin{array}{c}\text { Systemic } \\
\text { symptoms/signs }\end{array}$ & $\begin{array}{l}\text { Laboratory Test Results } \\
\text { (on admission) }\end{array}$ & $\begin{array}{c}\text { Number of vials } \\
\text { of Burma } \\
\text { Pharmaceutical } \\
\text { Industry Naja } \\
\text { kaouthia } \\
\text { antivenom }\end{array}$ \\
\hline 1 & $\begin{array}{l}\text { Age: } 65 \\
\text { Female }\end{array}$ & $\begin{array}{l}\text { Naja } \\
\text { mandalayensis }\end{array}$ & $116 \mathrm{~cm}$ & $\mathrm{R}$ upper leg & Bite marks, pain & Ptosis & $\begin{array}{l}\text { Urea } 3 \mathrm{mmol} / 1 \\
\text { Creatinine } 75 \mu \mathrm{mol} / 1 \\
\text { Sodium } 143 \mathrm{mmol} / 1 \\
\text { Potassium } 3.8 \mathrm{mmol} / 1 \\
\text { Chloride } 104 \mathrm{mmol} / 1 \\
\text { Bicarbonate } 27 \mathrm{mmol} / 1 \\
\text { Hb } 11.4 \mathrm{gm} / \mathrm{L} \\
\text { WBC } 14,000 \\
\text { Platelet } 176,000\end{array}$ & 4 \\
\hline
\end{tabular}




\begin{tabular}{|c|c|c|c|c|c|c|c|c|}
\hline 2 & $\begin{array}{l}\text { Age: } 55 \\
\text { Male }\end{array}$ & $\begin{array}{l}\text { Naja } \\
\text { mandalayensis }\end{array}$ & $53 \mathrm{~cm}$ & $\mathrm{R}$ hand & $\begin{array}{l}\text { Bite marks } \\
\text { Swelling of } 1 / 3 \text { of } \\
\text { limb, local } \\
\text { numbness, local } \\
\text { bleeding } \\
\text { Blisters and } \\
\text { local necrosis }\end{array}$ & None & Urea $4 \mathrm{mmol} / \mathrm{L}$ & $\begin{array}{l}4 \\
\text { (acute pyrogenic } \\
\text { reaction) }\end{array}$ \\
\hline 3 & $\begin{array}{l}\text { Age: } 4 \\
\text { Male }\end{array}$ & $\begin{array}{l}\text { Naja } \\
\text { mandalayensis }\end{array}$ & $60 \mathrm{~cm}$ & L lower leg & $\begin{array}{l}\text { Bite marks, } \\
\text { Swelling of } 1 / 3 \text { of limb } \\
\text { Bite site necrosis and } \\
\text { infection }\end{array}$ & $\begin{array}{l}\text { Nausea and Vomiting } \\
\text { Cyanosis } \\
\text { Respiratory distress }\end{array}$ & $\begin{array}{l}\text { Creatinine } 26 \mathrm{umol} / \mathrm{L} \\
\text { Urea } 7 \mathrm{mmol} / \mathrm{L} \\
\mathrm{Hb} 11.8 \mathrm{gm} / \mathrm{L} \\
\text { Platelet } 362,000\end{array}$ & 4 \\
\hline 4 & $\begin{array}{l}\text { Age: } 55 \\
\text { Female }\end{array}$ & $\begin{array}{l}\text { Naja } \\
\text { mandalayensis }\end{array}$ & $106 \mathrm{~cm}$ & $\mathrm{R}$ hand & Bite mark, local pain & None & Not done & None \\
\hline 5 & $\begin{array}{l}\text { Age: } 32 \\
\text { Male }\end{array}$ & $\begin{array}{l}\text { Naja } \\
\text { mandalayensis }\end{array}$ & $43.5 \mathrm{~cm}$ & L foot & $\begin{array}{l}\text { Pain, local swelling, } \\
\text { Local bite site necrosis, } \\
\text { infection }\end{array}$ & $\begin{array}{l}\text { Drowsiness, headache, } \\
\text { nausea/vomiting, } \\
\text { Bilateral ptosis, slurred } \\
\text { speech, blurred vision, } \\
\text { difficulty swallowing }\end{array}$ & Urea $5.8 \mathrm{mmol} / \mathrm{L}$ & 8 \\
\hline 6 & $\begin{array}{l}\text { Age: } 21 \\
\text { Male }\end{array}$ & $\begin{array}{l}\text { Naja } \\
\text { mandalayensis }\end{array}$ & $41.5 \mathrm{~cm}$ & $\begin{array}{l}\text { L Foot and } \\
\mathrm{R} \text { hand }\end{array}$ & $\begin{array}{l}\text { Bite marks, pain, local } \\
\text { swelling }\end{array}$ & Blurred vision & Not done & 4 \\
\hline
\end{tabular}




\begin{tabular}{|c|c|c|c|c|c|c|c|c|}
\hline 7 & $\begin{array}{l}\text { Age: } 29 \\
\text { Male }\end{array}$ & $\begin{array}{l}\text { Naja } \\
\text { mandalayensis }\end{array}$ & $105 \mathrm{~cm}$ & $\mathrm{~L}$ foot & $\begin{array}{l}\text { Bite marks, local } \\
\text { swelling }\end{array}$ & None & $\begin{array}{l}\text { Urea } 6.5 \mathrm{mmol} / \mathrm{L} \\
\text { Creatinine } 65.6 \mu \mathrm{mol} / \mathrm{L} \\
\text { Sodium } 147.5 \mathrm{mmol} / \mathrm{L} \\
\text { Potassium } 2.9 \mathrm{mmol} / \mathrm{L} \\
\text { Chloride } 106.7 \mathrm{mmol} / \mathrm{L} \\
\text { Bicarbonate } 27.3 \mathrm{mmol} / \mathrm{L} \\
\text { Hb } 13.7 \mathrm{gm} / \mathrm{L} \\
\text { Platelet } 201,000\end{array}$ & 4 \\
\hline 8 & $\begin{array}{l}\text { Age: } 22 \\
\text { Male }\end{array}$ & $\begin{array}{l}\text { Naja } \\
\text { mandalayensis }\end{array}$ & $79 \mathrm{~cm}$ & $\mathrm{R}$ hand & Bite marks & None & Not done & None \\
\hline 9 & $\begin{array}{l}\text { Age: } 35 \\
\text { Female }\end{array}$ & $\begin{array}{l}\text { Naja } \\
\text { mandalayensis }\end{array}$ & $28 \mathrm{~cm}$ & $\mathrm{~L}$ foot & Bite marks, local pain & Headache & $\begin{array}{l}\text { Urea } 3.6 \mathrm{mmol} / \mathrm{L} \\
\text { Creatinine } 66 \mu \mathrm{mol} / \mathrm{L} \\
\text { Sodium } 140 \mathrm{mmol} / \mathrm{L} \\
\text { Potassium } 3.2 \mathrm{mmol} / \mathrm{L} \\
\text { Chloride } 101 \mathrm{mmol} / \mathrm{L} \\
\text { Bicarbonate } 25 \mathrm{mmol} / \mathrm{L} \\
\mathrm{Hb} 11.9 \mathrm{gm} / \mathrm{L} \\
\text { WBC } 8,500\end{array}$ & $\begin{array}{l}\text { (15 vials of Indian } \\
\text { Polyvalent } \\
\text { antivenom) }\end{array}$ \\
\hline
\end{tabular}




\begin{tabular}{|c|c|c|c|c|c|c|c|c|}
\hline $\begin{array}{l}10 \\
\text { (see } \\
\text { also } \\
\text { detailed } \\
\text { case } \\
\text { report) }\end{array}$ & $\begin{array}{l}\text { Age: } 40 \\
\text { Male }\end{array}$ & $\begin{array}{l}\text { Naja } \\
\text { mandalayensis }\end{array}$ & $116 \mathrm{~cm}$ & $\mathrm{R}$ foot & $\begin{array}{l}\text { Swelling of } 2 / 3 \text { of limb } \\
\text { Pain at bite site } \\
\text { Painful right inguinal } \\
\text { lymph node enlargement } \\
\text { Local blistering, } \\
\text { possible infection and } \\
\text { necrosis }\end{array}$ & $\begin{array}{l}\text { "Drowsiness", ptosis, } \\
\text { blurred vision, } \\
\text { dysarthria, limited } \\
\text { mouth opening etc. (see } \\
\text { detailed Case History) }\end{array}$ & $\begin{array}{l}\text { Urea } 7.8 \mathrm{mmol} / \mathrm{L} \\
\text { Creatinine } 86 \mu \mathrm{mol} / \mathrm{L} \\
\text { Sodium } 140 \mathrm{mmol} / \mathrm{L} \\
\text { Potassium } 3.9 \mathrm{mmol} / \mathrm{L} \\
\text { Chloride } 102 \mathrm{mmol} / \mathrm{L} \\
\text { Bicarbonate } 25 \mathrm{mmol} / \mathrm{L} \\
\mathrm{Hb} 13.4 \mathrm{gm} / \mathrm{L} \\
\text { WBC } 15,150\end{array}$ & $4+4$ \\
\hline 11 & $\begin{array}{l}\text { Age: } 21 \\
\text { Male }\end{array}$ & $\begin{array}{l}\text { Naja } \\
\text { mandalayensis }\end{array}$ & $110 \mathrm{~cm}$ & $\mathrm{R}$ foot & $\begin{array}{l}\text { Scratch mark, pain, } \\
\text { swelling }\end{array}$ & None & Not done & 4 \\
\hline 12 & $\begin{array}{l}\text { Age: } 72 \\
\text { Male }\end{array}$ & $\begin{array}{l}\text { Naja } \\
\text { mandalayensis }\end{array}$ & $32 \mathrm{~cm}$ & L hand & Local swelling & None & Not done & None \\
\hline 13 & $\begin{array}{l}\text { Age: } 45 \\
\text { Male }\end{array}$ & $\begin{array}{l}\text { Naja } \\
\text { mandalyensis }\end{array}$ & $43 \mathrm{~cm}$ & L lower leg & $\begin{array}{l}\text { Local bite marks, local } \\
\text { bleeding }\end{array}$ & None & Not done & None \\
\hline 14 & $\begin{array}{l}\text { Age: } 26 \\
\text { Male }\end{array}$ & Naja kaouthia & $92 \mathrm{~cm}$ & $\mathrm{~L}$ foot & $\begin{array}{l}\text { Bite marks, pain, } \\
\text { swelling of left foot up } \\
\text { to the calf } \\
\text { Left tender inguinal }\end{array}$ & Blurred vision & $\begin{array}{l}\text { Creatinine } 143 \mu \mathrm{mol} / \mathrm{L} \\
\text { Urea } 6.2 \mathrm{mmol} / \mathrm{L} \\
\mathrm{Hb} 15 \mathrm{gm} / \mathrm{L}\end{array}$ & $\begin{array}{l}\text { (8 vials of Indian } \\
\text { Polyvalent } \\
\text { antivenom) }\end{array}$ \\
\hline
\end{tabular}




\begin{tabular}{|l|l|l|l|l|l|l|l|l|l|}
\hline & & & & lymphadenopathy & & Platelet 280,000 \\
\hline 15 & $\begin{array}{l}\text { Age: } 24 \\
\text { Male }\end{array}$ & Naja kaouthia & $33 \mathrm{~cm}$ & R hand & $\begin{array}{l}\text { Bite marks, local } \\
\text { swelling, numbness }\end{array}$ & Sleepiness & Not done \\
\hline 16 & $\begin{array}{l}\text { Age: } 27 \\
\text { Male }\end{array}$ & Naja kaouthia & $40 \mathrm{~cm}$ & R foot & $\begin{array}{l}\text { Bite marks, local } \\
\text { bleeding, swelling and } \\
\text { pain }\end{array}$ & None & Not done & Not done \\
\hline Spits & $\begin{array}{l}\text { Age: } 19 \\
\text { Male }\end{array}$ & $\begin{array}{l}\text { Naja } \\
\text { mandalayensis }\end{array}$ & $83 \mathrm{~cm}$ & Right eye & $\begin{array}{l}\text { Right eye redness, } \\
\text { burning sensation, } \\
\text { lacrimation, eyelid } \\
\text { swelling }\end{array}$ & $\begin{array}{l}\text { Headache } \\
\text { Nausea/Vomiting }\end{array}$ & None & None \\
\hline 18 & $\begin{array}{l}\text { Age: } 24 \\
\text { Male }\end{array}$ & $\begin{array}{l}\text { Naja } \\
\text { mandalayensis }\end{array}$ & $72 \mathrm{~cm}$ & Right eye & Eye redness & None & None \\
\hline
\end{tabular}




\section{Acknowledgements}

We are grateful to Dr U Tun-Pe (DMR) for advice, to Dr Wolfgang Wüster (University of Bangor) for reviewing the manuscript, to Mr Ashok Captain (Bombay Natural History Society) for searching for specimens from Burma and to Nay Myo Hlaing for help with preparing the map. Funding support from the Australian Department of Foreign Affairs and Trade towards the Myanmar Snakebite Project is gratefully acknowledged.

\section{Captions to figures}

Figure 1

Monocled cobra (Naja kaouthia) from near Kolkata, West Bengal, India spitting its venom at an earthenware vessel about 1 meter away. Inset shows tracks madeon the vessel by the two jets of venom (credit Julian White, 2010). To illustrate that some Indian populations of $N$. kaouthia are capable of spitting their venom defensively (see also Santra and Wüster, 2017).

Figure 2

Map of locations of cobra specimens. Key: red spot = Naja mandalayensis (this study); black triangle $=N$. kaouthia (this study); green square $=N$. mandalayensis (Slowinski and Wuster, 2000)

Figure 3

Cobra fangs (credit Julian White)

A-C Discharge orifices of three Naja mandalayensis showing lack of grooves

D Naja kaouthia, from Myanmar showing discharge orifices set in a groove

E Naja naja, from Kolkata showing discharge orifice set in a groove

Figure 4 
Monocled cobra, Naja kaouthia, specimens from Kyaukse: showing a - monocle pattern on dorsal surface of hood in a preserved specimen; and b - lack of dark spots on the throat above the anterior dark band and the two "false eye" spots laterally

\section{Figure 5}

Mandalay spitting cobra, Naja mandalayensis, specimen from Kyaukse: showing lack of dorsal monocle marking, dark spots on throat in front of anterior dark band (on ventral scales 17-23), and pale coloured ventral and sub-caudal scales.

\section{Figure 6}

Mandalay spitting cobras (N. mandalayensis): Living specimen from Taungdwingyi showing: a - barely-discernible spectacle/U-shaped hood mark visible in the interstitial skin of the dorsal surface of the hood, which is common in this species; and $b$ - dark markings on the throat in front of the first dark ventral band (credit Mark O'Shea)

Figure 1.

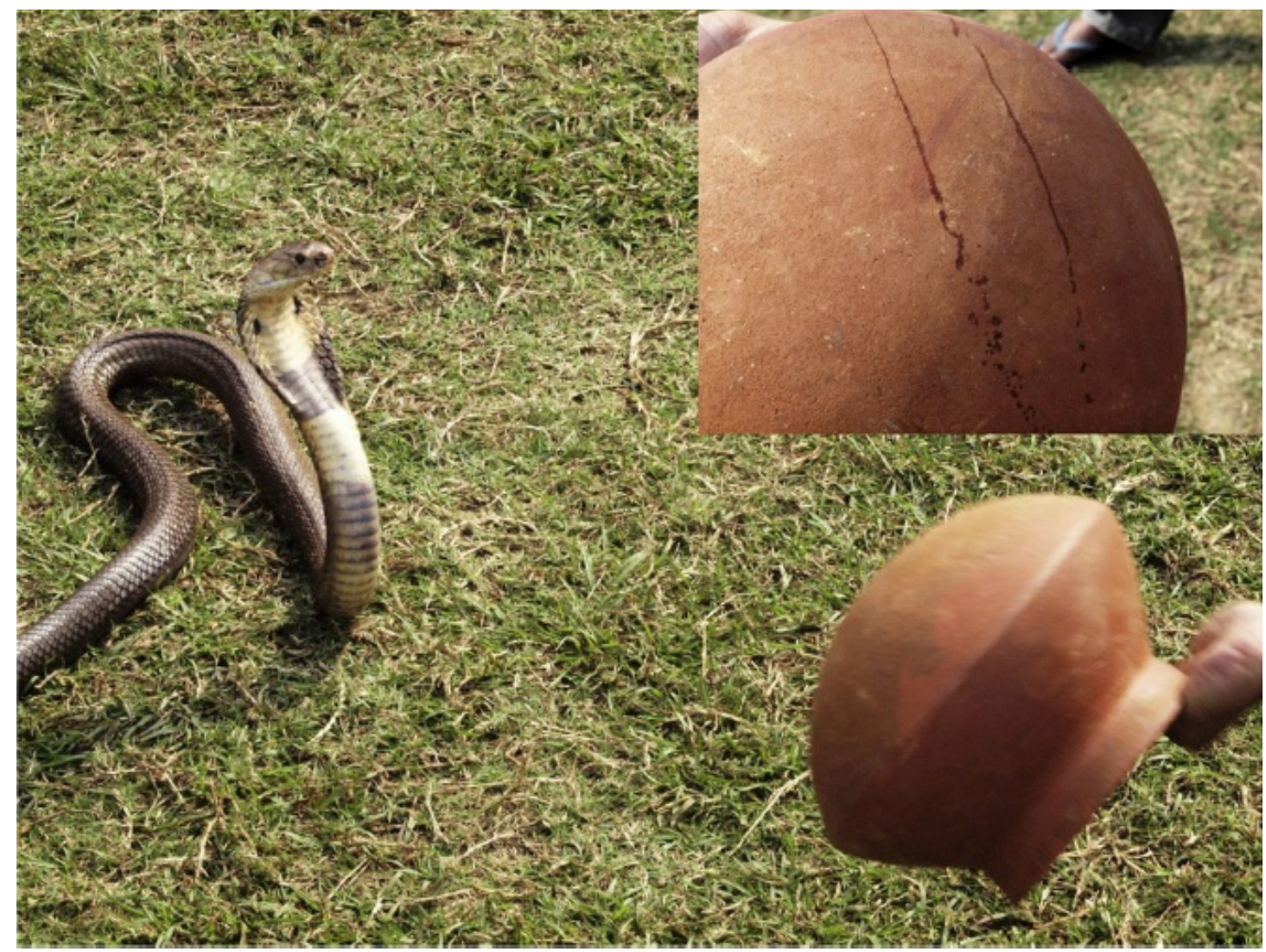


Figure 2.

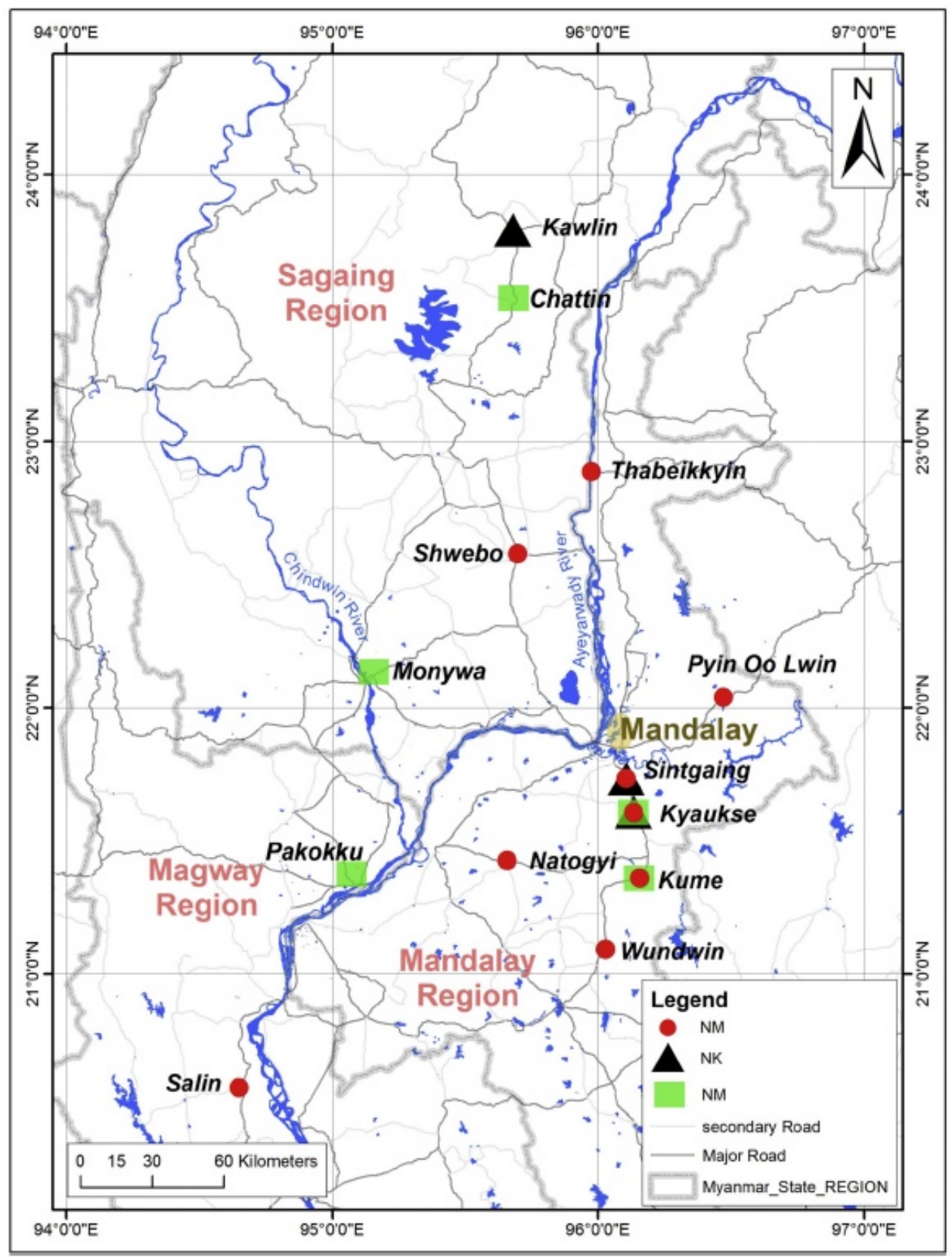


Figure 3.

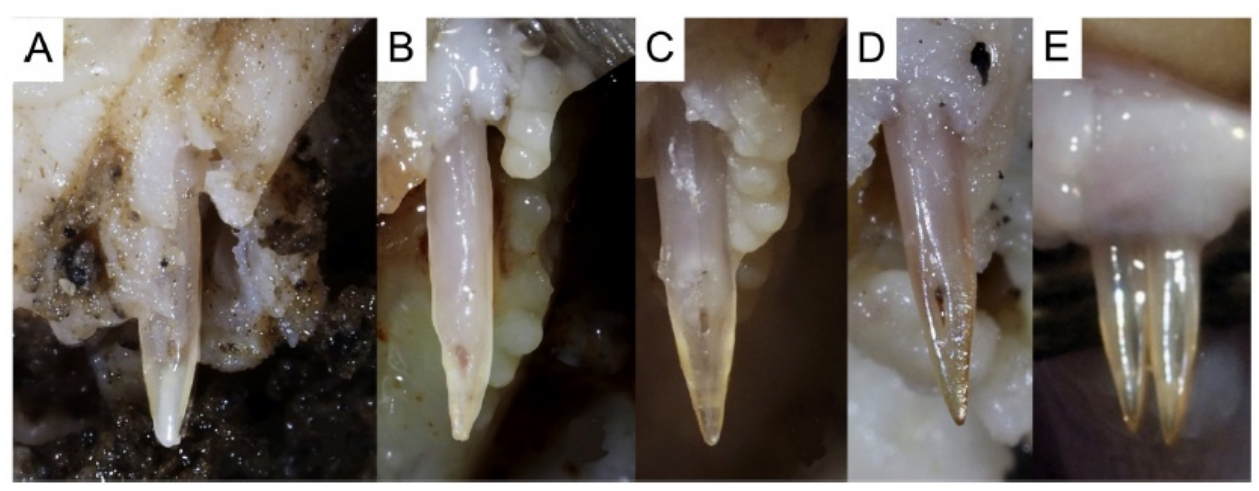




$$
\begin{aligned}
& \text { L } \\
& \&
\end{aligned}
$$


Figure 5.
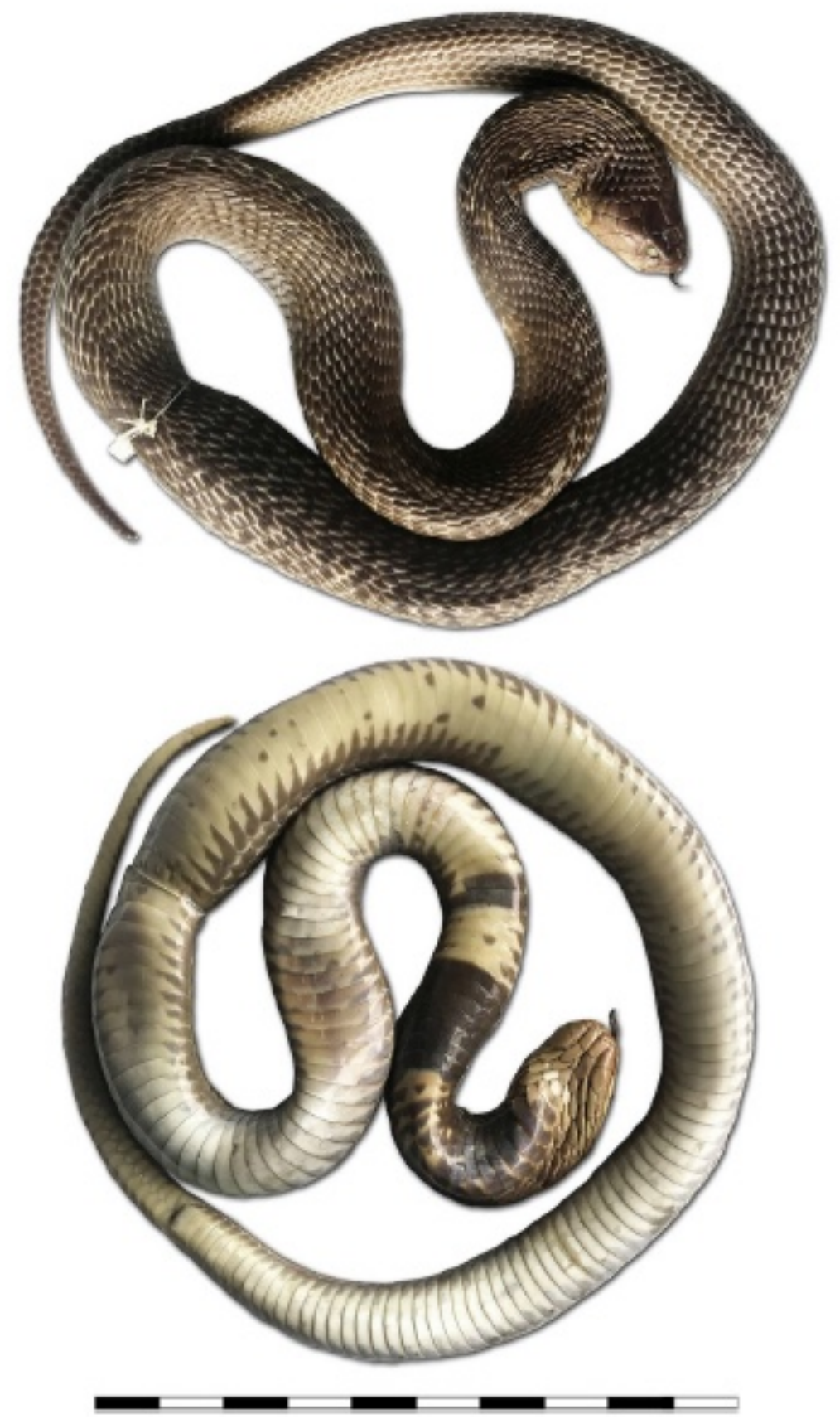
Figure 6.
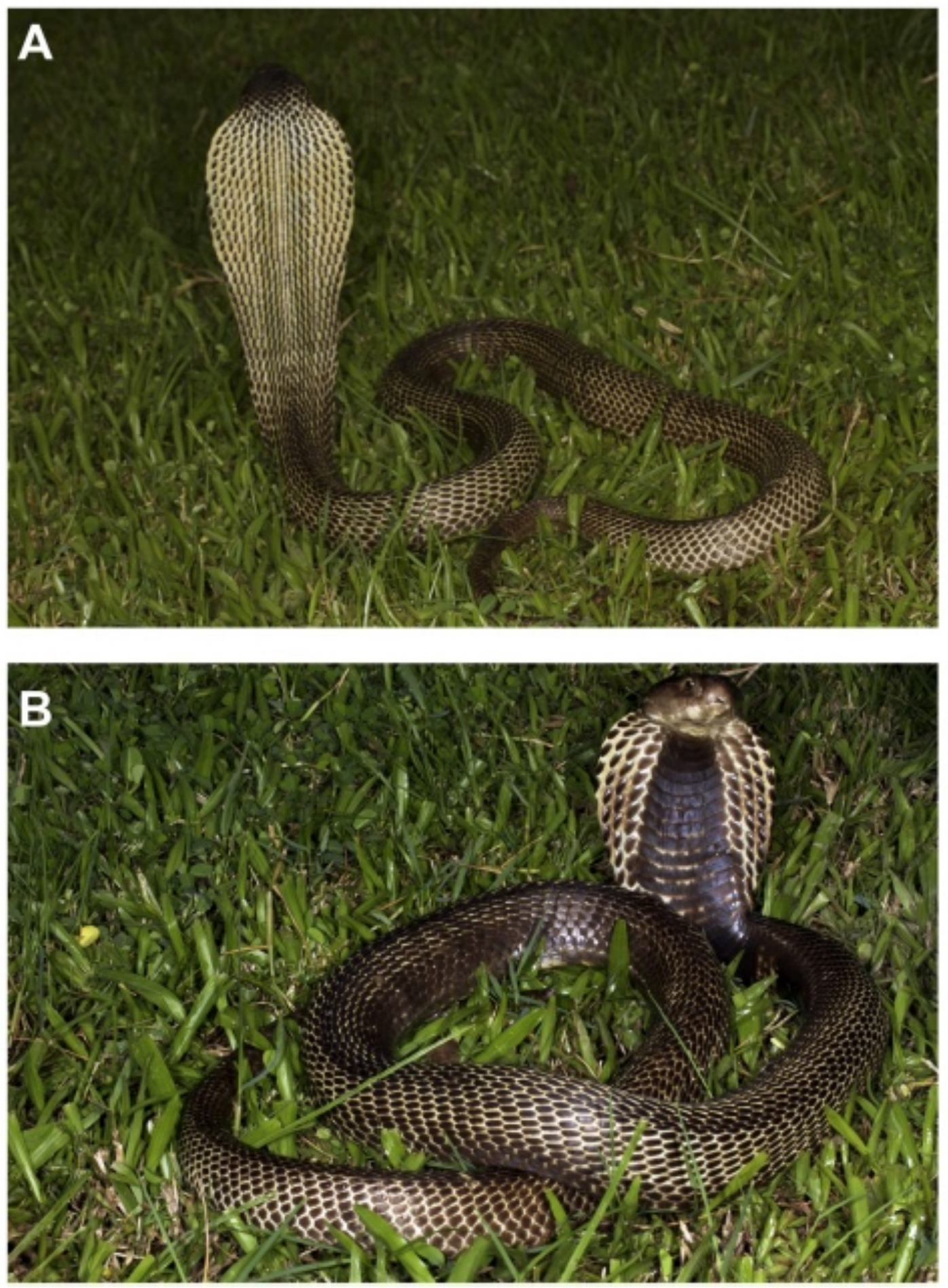